\title{
SS-024 臨床的問題にみる「ふつう」概念
}

\author{
企画代表者: 黒石 憲洋 (日本教育大学院大学) \\ 話題提供者: 生井 裕子 (桐朋学園) \\ 話題提供者: 水澤慶緒里 (関西学院大学) \\ 話題提供者: 新堂 研一 (神戸家庭裁判所) \\ 指定討論者: 伏木 久始＃（信州大学) \\ 指定討論者: 松井洋 (川村学園女子大学) \\ 司会者: 佐野予理子 (清泉女学院大学)
}

周囲の他者との関倸性や調和を重視する日本人にとって、自分が他者や基準から逸脱しておらず「ふ つう」であるという認識は、適応感をもたらすという重要な意味をもつ。この「ふつう」には、他者を 基準として自己を評価する (other-anchoring) 側面と、自己の価值を投影して他者を判断する（selfanchoring）側面があるが、いずれの側面も適応に関係している。前者では、他者の眼や周囲の期待と しての「ふつう」を強く意識しすぎて、なんとかそこに到達しょうとして苦しむ場合や、後者では、高 すぎる基準をできてあたりまえと捉えて、その基準に達しない他者を受け入れられずに孤立してしまう 場合もある。本シンポジウムでは、具体的な臨床的問題を取り上げた話題提供を受けて、教育的・文化 的観点から指定討論をいただき、個人の適応／不適応という問題について「ふつう」概念を中心として、 フロアを交えた活発な議論をおこないたい。

\section{生井 裕子（桐朋学園）}

日本人にとって、「ふつう」であることは、高い安静状態と低い否定的感情と関連が樑いことが示唆されている。しかし、 教育相談所を訪れるクライエントとの面接では、「ふつう」への囚われやそれに伴う否定的感情が語られることが多い。今 回は、「ふつう」の捉え方によっては、その人の適応にネガティブに関連しうるという観点から、「ふつう」の捉え方やその 変化がどのように適応と繋がるのかに焦点をあて、話題提供を行いたい。

\section{水澤慶緒里（関西学院大学）}

成人用過剩適応尺度（水澤，2013）は、「ふつう」という視点で考えれば「ふつう」以下を回避しょうとする「評価懸念」 「援助要請への躊踷」「ふつう」以上を求める「多大な評価希求」「強迫性格」の 4 下位尺度で構成されると考元られる。特 に「評価懸念」は頑健に心身の不健康との関連が示されている。そこで「評価懸念」に注目し、臨床群と健常社会人群との 違い、また診断名間、業種間の違いを量的デー夕に基づき検討する。

\section{新堂 研一（神戸家庭裁判所）}

話題提供者は、家庭裁判所調查官として非行少年やその保護者と面接し、「ふつう」に関する話題を聴取してきた。その 中で「ふつう」への意識やこだわりが適応感に影響を与え、そのことが直接または間接的に非行のメカニズムに慗がってい ると考元られる多くの事案に接してきた。非行臨床における「ふつう」への認識の諸相について、少年や保護者の語りを中 心に話題提供を行い、併せて非行少年に対する質問紙調查の結果等を報告する。 